\title{
A infância representada no livro escolar: tipos de textos e estereótipos sociais
}

TERESA CONCEIÇÃO MENDES CASTRO

Universidade do Minho, Braga, Portugal

RUI MANUEL NASCIMENTO LIMA RAMOS

Universidade do Minho, Braga, Portugal

RESUMO

Esta investigação inscreve-se dominantemente no âmbito dos estudos da criança e ancora a sua área específica nas questões linguísticas, assumindo os pressupostos teóricos e metodológicos da análise do discurso (de tradição francófona), considerando também contributos de áreas conexas. Analisa textos de manuais/livros escolares usados no sistema de ensino português, pretendendo tornar visíveis as imagens que estes constroem das crianças e da infância, bem como os recursos linguísticos mais relevantes associados a tal construção. Procura desvendar a representatividade das tipologias textuais nos manuais e de que forma estas contribuem para a construção das referidas imagens. Conclui que as crianças dos textos são seres sem voz e sem poder, consumidoras, mas não coprodutoras de cultura, com os textos inculcando valores conformadores da manutenção da ordem social estabelecida, sendo a forma como as tipologias textuais estão organizadas contribuidora para se alcançar esse propósito.

\section{PALAVRAS-CHAVE}

educação; análise do discurso; tipologia textual; criança; livro escolar. 


\section{CHILDHOOD REPRESENTED IN THE TEXTBOOK: TYPES OF TEXTS AND SOCIAL STEREOTYPES}

\section{ABSTRACT}

This research forms primarily part of the child studies and is based on its specific field of linguistic issues, assuming the theoretical and methodological assumptions of the speech analysis (of French-speaking tradition), having also regard the inputs of related fields. It analyses texts from handbooks/textbooks used on the Portuguese educational system, intending to reveal pictures that these books construct about children and childhood, as well as the most relevant linguistic resources associated with such construction. This paper aims at unravelling the representation of the text typologies in the handbooks and how these can contribute for building of such pictures. From this, one can conclude that children from the texts are voiceless and have no power, they are consumers but not co-producers of culture, with these texts instilling conservative values for maintaining the established social order, but also that the way texts typologies are organized to contribute for reaching that propose.

\section{KEYWORDS}

education; discourse analysis; text typology; child; textbook.

\section{LA INFANCIA REPRESENTADA EN EL LIBRO DE TEXTO: TIPOS DE TEXTOS Y ESTERIOTIPOS SOCIALES}

\section{RESUMEN}

Esta investigación se ensere en el ámbito de los estudios del niño y más precisamente en la área de las cuestiones lingüísticas, asumiendo los presupuestos teóricos e metodológicos de la análisis del discurso (de tradición francófona), considerando también aportes de las áreas conexas. Analiza textos de manuales/libros escolares usados en el sistema de enseñanza portugués, pretendiendo tornar visibles las imágenes que este construyen de los niños y de la infancia, bien como los recursos lingüísticos más relevantes asociados a esa construcción. Busca desvendar la representatividad de las tipologías textuales en los manuales y de qué forma contribuyen para la construcción de las referidas imágenes. Concluye que los niños de los textos son seres sin voz y sin poder, consumidores, pero no coproductores de cultura y que los textos inculcan valores conformadores de manutención del orden social establecido, mas también que la forma como las tipologías textuales están organizadas contribuye para alcanzar ese propósito. 


\section{INTRODUÇÃO}

O presente estudo pretende tornar visíveis as imagens que os textos dos manuais/livros escolares de português utilizados em Portugal no $1^{\circ}$ ciclo do ensino básico ${ }^{1}$ constroem das crianças e da infância, assim como os recursos linguísticos/ textuais mais relevantes associados a tal construção. Considera-se importante compreender essas imagens por se acreditar que elas são capazes de influenciar as perceções das crianças-leitoras e, consequentemente, suas ações e posturas perante os outros e perante si mesmas.

A abordagem teórica e metodológica pretende ser pluridisciplinar e interdisciplinar, considerando a centralidade da criança como eixo orientador da investigação. $\mathrm{O}$ corpus de análise é composto de textos dos manuais escolares utilizados pela maioria das crianças das escolas portuguesas do $4^{\circ}$ ano de escolaridade. Como área científica central de pesquisa, elege-se a análise do discurso, também ela espaço de confluência de vários saberes, por ser a que melhor serve os propósitos desta investigação, na medida em que proporciona os fundamentos teóricos e a metodologia mais adequados para os fins em vista. $\mathrm{O}$ objetivo deste estudo não é, contudo, apenas trabalhar os aspetos linguísticos, mas abarcar um espaço mais abrangente, em uma busca de contributos de várias pesquisas concretizadas em volta dos estudos da criança (com conexões fortes a questões de educação). Manter-se-á presente que os manuais escolares assumem a sua importância por funcionarem em sociedade, e os textos que neles são inseridos serão entendidos em sua globalidade, considerando os discursos em contexto.

Conscientes de que só podemos conceber a existência do ser humano quando inserido numa sociedade, consideram-se fundamentais vários contributos oriundos da sociologia (Giddens, 1997; Moore, 2002; Pais, 1998). Na verdade, qualquer atividade realizada por um indivíduo só se tornará visível e pertinente quando inscrita em um contexto de permanente interação social. Essas atividades são regidas por normas que asseguram a coesão social e regulam as condutas dos indivíduos, garantindo que ninguém age completamente à margem das convenções sociais. Também a criança se torna, à nascença, herdeira involuntária da cultura subjacente à sociedade em que está inserida, e esta vai condicionar grandemente a sua forma de ser e de estar perante o mundo. Mas a criança não é apenas assimiladora de cultura, ela interpreta e participa na construção dessa mesma cultura, como lembram os estudos realizados no âmbito da sociologia da infância (Sarmento e Pinto, 1997; Sarmento, 2000, 2004, 2005, 2007; Rasmussen, 2004; Fernandes e Vidigal, 2005).

A sociologia da infância tem contribuído para definir os conceitos de "criança" e "infância" com o objetivo de garantir um lugar pleno de direitos à criança, enquanto cidadão ativo e participativo na vida e nas decisões da sociedade, tal como qualquer outro cidadão. Segundo os sociólogos da infância, a criança não é um ser passivo,

1 Corresponde às séries iniciais no Brasil. Em Portugal, o ensino básico encontra-se organizado em três ciclos: o primeiro abarca quatro anos, o segundo, dois anos, e o terceiro estende-se por mais três anos. Segue-se o ensino secundário, com duração de três anos. 
como tradicionalmente se pensava, mas um indivíduo com capacidade para participar na vida da sociedade e dar a sua opinião sobre variados assuntos que dizem respeito à vida nessa mesma sociedade.

Não é possível pensar em criança e infância sem pensar na escola, enquanto instituição social criada fundamentalmente para educar os indivíduos, especialmente nos primeiros anos de vida. Ao longo dos tempos, assistiu-se à generalização da institucionalização da escola pública, com o Estado assumindo o papel de proteger e educar as crianças e atribuindo à escola a função de transmitir o saber socialmente válido e indispensável para garantir determinada cultura. Por esse motivo, a escola sempre teve uma função socializadora, empenhando-se na formação moral e cívica dos alunos, para além da "instrução" (Ariès, 1981; Giddens, 1997; Magalhães, 1997; Pais, 1998; Adão, 2005; Correia, 2005). Com o conceito "escola" surge o conceito "aluno", enquanto construção social criada pelos adultos, que sempre detiveram o poder de organizar a vida dos não adultos (Brougère, 1998; Lopes, 2005; Sacristán, 2003).

Dentro da escola, nomeadamente na disciplina de português, os manuais escolares têm assumido, ao longo dos tempos, extrema importância no processo de ensino e aprendizagem (Apple, 2002; Castro, 2008; Castro et al., 1999; Choppin, 1992; Claudino,2011; Crispim, 2002; Dionísio, 2000; Ramos, 2009) e determinado muito do que se passa em contexto de sala de aula, contribuindo para a socialização dos alunos.

A análise do discurso, enquanto área de confluência entre vários âmbitos do saber que colaboram na análise e descrição dos discursos produzidos pelos indivíduos de determinada sociedade, recebe contributos da pragmática linguística (Austin, 1962; Benveniste, 1975; Fonseca, 1994; Maingueneau, 1990, 1996; Searle, 1969), que considera como centro da investigação o homem na língua e no discurso. O mundo é construído no e pelo discurso, e, segundo essa perspetiva, os textos são instrumentos de construção desse mundo, pois não é possível conceber um ato discursivo sem visar alguma finalidade ilocucional. É, pois, assumindo o homem como ser social que a análise do discurso (Charaudeau e Maingueneau, 2006; Fonseca, 1992a; Foucault, 1969; Kerbrat-Orecchioni, 1996; Ramos, 2009; Van Dijk, 1985) analisa os textos/ discursos, tendo por base o uso efetivo da língua em contexto. Ao considerar-se o homem em permanente interação com os outros, ou seja, a viver em sociedade, não é possível deixar de refletir nos pressupostos do interacionismo sociodiscursivo, principalmente nos trabalhos de Bronckart $(1985,2009)$, considerando os discursos "formações discursivas" produzidas no seio de "formações sociais".

$\mathrm{Na}$ análise dos textos/discursos importa, ainda, ter em conta os trabalhos de Adam (1990,1992), no âmbito da linguística textual, uma vez que aqui se entendem os textos/discursos enquanto unidades configuracionais heterogéneas e complexas, mas também coerentes. Os textos/discursos configuram-se em planos de organização que se encontram em constante interação. Nesse campo de estudos surgem como incontornáveis os conceitos de "géneros de discursos", "tipologias textuais", "contexto", "coesão e coerência". Os textos são tessituras extremamente complexas, organizadas em torno de sequências prototípicas dominantes e estas em estruturas composicionais, convergindo para um significado global. Mas, como refere Bakhtine (1992), os textos não nascem do nada, do silêncio absoluto. Todas as produções 
discursivas se ancoram em discursos anteriores, preveem discursos subsequentes e inscrevem-se em determinadas conjunturas sociais, tornando incontornável a noção de "polifonia" ou "heterogeneidade enunciativa" - as marcas de outras vozes, inscritas no discurso por meio de estratégias linguísticas mais ou menos explícitas. Estamos, portanto, perante processos de modalização concretizados em "reportórios interpretativos" (Potter e Wetherell, 1987), selecionados pelo enunciador para tornar possível a evocação de "frames" (Fillmore, 1975), ou quadros concetuais convocados durante a leitura dos textos. Esse processo assenta na enciclopédia de saberes do alocutário, que se vai construindo ao longo de sucessivas leituras, bem como por vivências individuais e sociais.

\section{METODOLOGIA E CORPUS DE ANÁLISE}

Como antes referido, os textos em análise foram recortados de três manuais/livros escolares de português do $4^{\circ}$ ano do $1^{\circ}$ ciclo do ensino básico de Portugal, a saber:

1. Pereira, C. et al. Pasta mágica - lingua portuguesa $4^{\circ}$ ano. Porto: Areal Editores, 2006 (doravante Pasta mágica);

2. Rocha, A.; Lago, C. e Linhares, M. Amiguinhos - lingua portuguesa $4^{\circ}$ ano. Lisboa: Texto Editores, 2006 (doravante Amiguinhos);

3. Marques, M. J.; Santos, M. A. e Gonçalves, A. Giroflé-lingua portuguesa $4^{\circ}$ ano. Lisboa: Santillana-Constância, 2006 (doravante Giroflè).

Esses manuais foram escolhidos com base em informações facultadas pela Direção-Geral da Educação, segundo a qual foram os mais utilizados no $4^{\circ}$ ano do $1^{\circ}$ ciclo do ensino básico. Note-se que, em Portugal, cada escola tem liberdade para fazer a sua escolha de manuais que os professores consideram mais adequados para $o$ ensino, de entre os livros presentes no mercado e devidamente certificados por entidades reconhecidas pelo Ministério da Educação e Ciência. Ainda de acordo com os dados recolhidos, esses três livros cobrem um total de 54,35\% (respetivamente $31,17 \%, 11,91 \%$ e $11,27 \%$ ) dos alunos matriculados no $4^{\circ}$ ano de escolaridade no ano letivo de 2010/2011 e podem ser considerados amostra representativa da totalidade dos manuais utilizados no país. Permaneceram em utilização até ao final do ano letivo de 2012/2013, findo o qual as escolas optaram por novos manuais para $\mathrm{o}$ ano de escolaridade seguinte.

$\mathrm{O} 4^{\circ}$ ano foi o escolhido por constituir o último passo do $1^{\circ}$ ciclo do ensino básico, etapa fundamental para todo o percurso educativo do indivíduo, com capacidade de repercutir as boas e más experiências por toda a vida. Nesse ano letivo, os alunos já adquiriam competências para encarar textos extensos com autonomia e refletir sobre eles.

Depois de analisados todos os textos presentes nesses manuais escolares, procedeu-se à seleção daqueles que serviriam de suporte à presente investigação. Para o efeito, utilizou-se como critério a construção linguística de imagens de crianças ou da infância nos textos, tendo sido selecionados todos aqueles que constroem, apresentam ou convocam, de forma explícita ou implícita, figuras ou imagens 
de crianças ou da infância, concretizadas na presença de personagens infantis, de crianças como narradores ou sujeitos de enunciação, assim como a apresentação ou construção de "mundos" prototípicos da criança: brincadeiras, atitudes, relações, linguagem, cenários etc. Por oposição, foram excluídos todos os textos que não apresentam as características referidas. Foi, assim, obtido um corpus global de 110 textos.

Os textos selecionados foram classificados segundo a tipologia textual definida pelo Dicionário Terminológico, ${ }^{2}$ para o qual "os textos, para além das propriedades fundamentais da textualidade, apresentam estruturas verbais peculiares, semânticas e formais, e marcas pragmáticas que possibilitam a sua classificação em tipos ou géneros". Esse documento oficial, da responsabilidade do Ministério da Educação e Ciência português e orientador das práticas letivas no ensino básico e secundário, apresenta uma classificação tipológica dividida em oito categorias de textos, com base nas respetivas sequências dominantes (Adam, 1992): conversacionais, narrativos, descritivos, expositivos, argumentativos, instrucionais ou diretivos, preditivos e literários.

Segundo Maingueneau (2005, p. 140), “a maneira pela qual o texto é produzido e pela qual é consumido estão ligadas”, ou seja, os textos são produzidos tendo em vista determinado público, sendo que "a própria rede institucional desenha uma rede de difusão, as características de um público, indissociáveis do estatuto semântico que o discurso se atribui [...]. O 'modo de difusão' vai de mãos dadas com o modo de consumo do discurso, isto é, com o que se 'faz' dos textos, como eles são lidos, manipulados [...]" (Maingueneau, 2005, p. 141).

Nesse sentido, os textos presentes nos manuais escolares são produto de uma dupla intencionalidade (excetuando os textos inéditos, escritos propositadamente para determinado manual): a do seu autor original e a do autor do manual. Se, numa primeira instância, o texto foi produzido com determinada intencionalidade comunicativa e visando determinado público, numa segunda instância o texto (ou parte desse primitivo texto) foi escolhido com uma intencionalidade comunicativa que pode ser (e é, muitas vezes) divergente da original, assim como o público-alvo pode ser diferente, como é o caso, por exemplo, de excertos de obras concebidas para leitores adultos e que são utilizados nos manuais escolares para serem estudados por crianças. Concorda-se aqui, pois, com Maingueneau (2005, p. 188), quando afirma que "para nós, mesmo quando se republicam textos, mesmo quando se produzem novos textos que parecem resultar da mesma competência discursiva, não se poderia falar dos mesmos discursos". É, pois, atendendo a esses pressupostos que se entendem os textos presentes nos livros escolares, ainda que possam ser excertos de textos mais extensos, como sendo sujeitos a processos de retextualização e recontextualização, transformando-se, assim, em novos textos (Castro, 2007), enformados por esse dupla intenção comunicativa.

Não podemos esquecer que o manual escolar ocupa um lugar central (Choppin, 1992) no processo de ensino e aprendizagem e que é reprodutor do conhecimento entendido como socialmente válido, ao mesmo tempo em que funciona

2 Disponível em: $<$ http://dt.dge.mec.pt/>. Acesso em: 17 out. 2017. 
como aparelho de controlo social (Apple, 2002). Assim sendo, o manual escolar é visto por alunos, pais e (muitos) professores como o detentor do saber considerado socialmente válido, podendo, até, ser visto como detentor da verdade absoluta por parte, principalmente, dos alunos. E, se o manual escolar ocupa uma tão importante posição na nossa sociedade, ainda mais relevante se torna o manual de português, uma vez que é por meio dele que o aluno vai contactar mais de perto com o modo escrito da sua língua, aprendendo a manipular os mecanismos linguísticos que the permitem utilizá-la para transmitir informações, mas, mais importante que isso, para exercer influência e poder sobre os outros. É sobretudo na aula de português que os alunos aprendem a manipular os mecanismos linguísticos que lhes permitirão ser leitores e escritores fluentes e competentes, contribuindo essa competência para alcançar sucesso em sua vida escolar, social e profissional.

Dessa forma, essa disciplina é de importância crucial no percurso académico dos alunos, não sendo por acaso que o próprio poder político lhe atribui uma elevada carga horária. A escola reconhece a importância que essa disciplina tem na base da construção de todo o conhecimento e, dessa forma, a sociedade também. Como lembra Maingueneau (1997, p. 63), "é preciso [...] não perder de vista que o termo 'escola' não é unívoco. Ele remete a um só tempo a uma instituição, a práticas, a lugares... à escola que se legitima ao enunciar - é tudo isto ao mesmo tempo". Assim sendo, os manuais escolares de português são enformados por um enquadramento social que os reveste de enorme importância e os torna veículos por excelência de transmissão de valores, de ideologias e de modos de ser e estar na vida e na sociedade. Essa transmissão de conhecimento e de valores é particularmente expressa, de forma mais ou menos explícita, nos textos que servem e tornam possível a finalidade comunicativa com que são escolhidos, criados ou recriados.

$\hat{E}$, pois, nesse contexto que se entendem os textos presentes nos manuais escolares de português como veículos importantes na transmissão e na construção de cenários prototípicos de "normalidade", capazes de criar imagens da infância na sociedade, influenciando as formas de pensar e agir dos potenciais utilizadores (as crianças, em primeira instância; os pais e professores, em segunda instância).

\section{TIPOLOGIAS TEXTUAIS}

A análise realizada permitiu verificar que o corpus textual é constituído maioritariamente por textos narrativos (45 textos), seguidos dos descritivos (29 textos). Menos representados, mas ainda assim bastante presentes, encontrámos os instrucionais (15 textos) e os literários (12 textos). Os expositivos (9 textos) apresentam uma frequência mais baixa. Verificámos que nem todas as tipologias se encontram representadas de igual forma no corpus definido, valorizando-se, sem dúvida, os textos narrativos em primeiro lugar e os descritivos, logo a seguir. As restantes tipologias elencadas pelo Dicionário Terminológico (textos conversacionais, argumentativos e preditivos) não se encontram representadas entre os textos selecionados.

Pode afirmar-se que, genericamente, o corpus recortado reproduz o cenário geral dos livros escolares pelos quais ele foi construído, no que respeita aos tipos de texto e sua representatividade. 


\section{OS TEXTOS NARRATIVOS}

O facto de os textos narrativos predominarem em todos os manuais analisados é facilmente explicado por quase todos serem excertos recortados de contos de potencial receção infantil, o que, aliás, é já tradição na conceção dos livros escolares. Como afirma Dionísio (2000), esse tipo de literatura, mesmo que implicitamente, desempenha uma missão educadora, que a escola potencia. Também Bastos (1998), Ramos (2009) ou Ramos e Ramos (2015) sublinham que, apesar da importância atualmente reconhecida às dimensões lúdica e estética da literatura infantil, a sua dimensão pedagógica ganha relevo para muitos autores. Essa circunstância favorece decisivamente o uso de textos da literatura infantil nos livros escolares.

No entanto, é frequente esses textos apresentarem-se como narrativas incompletas, faltando-lhes uma ou mais fases da estrutura narrativa, segundo as propostas de Adam (1992). Em muitos casos, a narrativa permanece incompleta, não se propondo qualquer trabalho ao aluno no sentido de colmatar essa lacuna (por exemplo, pedindo-lhe que complete a história), criando falsas expectativas, assim como dificultando ou mesmo impossibilitando a compreensão leitora.

Do conjunto dos 45 textos narrativos, apenas 20 são textos completos, sendo 8 inéditos. Os restantes são excertos recortados de narrativas mais longas. Quando confrontados os textos com as obras originais, verifica-se que 10 textos foram recortados do início da narrativa, 6 foram retirados da parte destinada à intriga, e apenas 2 excertos pertencem ao final do texto original. Como se pode verificar, poucas vezes o autor do manual opta por fazer um recorte do final de uma narrativa, e essa opção é facilmente explicada pelos problemas de coesão, coerência e compreensão leitora que acarreta aquando da leitura do texto, uma vez que se perdem partes importantes, impossibilitando a sua compreensão integral. Mas esse não é um problema apenas desse tipo de recorte, podendo o mesmo acontecer com os excertos retirados do meio das narrativas, uma vez que nem sempre é assegurada a continuidade textual, provocando problemas de coesão e coerência (Castro, 2007). Trata-se, por exemplo, da ocorrência de expressões com valor anafórico que não possuem explicação no excerto presente no manual e que provocam estranheza no leitor, dificultando, enviesando, ou mesmo impedindo, a compreensão leitora. É o caso, por exemplo, do texto seguinte, que se inicia com discurso direto, sem qualquer tipo de introdução que situe a narrativa e apresente as personagens:

- Bom-dia - disse a Menina. - O que é que me trouxeste hoje? (Pasta mágica, p. 140)

$\mathrm{O}$ artigo definido que precede o nome próprio marca habitualmente um referente já conhecido do leitor, indicando, portanto, uma relação anafórica que não se concretiza no texto. Nesse caso, não se tratando de um referente genérico, e não podendo funcionar como anafórico, o artigo assume um valor catafórico, o que não deixa de constituir uma forma de criar tensão - potenciadora da atração, se o leitor se sentir compelido a continuar a leitura para resolver o vazio de informação; ou desfavorável à leitura, se constituir um problema que o leitor não consiga resolver. Nesse caso, a segunda hipótese é a mais provável, uma vez que o leitor nunca encontrará informação para resolver essa lacuna deixada pelo excerto. 
Esse problema é agravado pelo advérbio de tempo hoje, que estabelece uma relação cronológica e faz pressupor que aquele não é um primeiro encontro, nem a primeira vez que aquela personagem traz alguma coisa para mostrar à menina.

Quando os excertos são recortados do início das narrativas originais, os problemas de coesão e coerência são muito reduzidos. No entanto, porque também os textos são muito reduzidos, apresentam o problema de não conterem todas as partes constituintes da narrativa (Adam, 1992; Castro, 2007), tornando-se textos incompletos, podendo dificultar a compreensão leitora, mas, com certeza, defraudando as expectativas do leitor.

Se atentarmos no tipo de enunciador presente nos textos narrativos desse corpus, verificamos que são 31 aqueles nos quais encontramos um enunciador externo do tipo omnisciente. Mas esse não é o único tipo de narrador existente nos textos narrativos. Deparamos com alguns em que o enunciador é interno ao texto (14 textos), sendo que 10 textos apresentam um narrador autodiegético e 4 apresentam um narrador homodiegético. Nesses textos encontramos sempre um narrador que enuncia utilizando a primeira pessoa e, quase sempre, por meio da voz de uma criança, como acontece no seguinte exemplo:

Vi o que estava dentro da caixa e soltei um grito que espantou a Tareca. (Pasta mágica, p. 59)

Essa é uma dupla estratégia de aproximação à criança-leitora: por um lado, temos alguém que narra algo que lhe aconteceu; por outro, essa narrativa é realizada por uma criança. Trata-se, portanto, de uma criança que fala para outra criança, o que potencia a aproximação entre locutor e alocutário. Promove-se, assim, a adesão inicial (atraindo o leitor virtual) e a manutenção do interesse pela leitura: o narrador, ao identificar-se com a criança-leitora, favorece a sua identificação com ele, aproxima o universo de ambos (espaços, ações, sentimentos, experiências, crenças, valores...) e possibilita à criança-leitora dar um sentido ao que lê, pela incorporação da nova informação que a leitura do texto lhe traz em seu universo de referências, em suas experiências e saberes concretos.

Como seria de esperar, esses textos são narrativas que giram em torno de universos infantis, inscritos em diversos cenários, com ligeira predominância dos cenários interiores em relação aos exteriores. No grupo das narrativas que apresentam uma diegese inscrita em cenários exteriores, destacam-se os quadros de rua e praia, embora também surjam referências à floresta ou ao céu. Esses cenários podem aparecer construídos de forma explícita na materialidade linguística dos textos, mas também se encontram outros cuja construção linguística dos cenários é realizada de forma implícita. Nesses casos, é a seleção lexical (reportório interpretativo) realizada no texto que configura e suporta a criação de frames sobre esses espaços, por meio de processos inferenciais que se baseiam, sobretudo, nos conhecimentos que o leitor possui do mundo e da leitura de outros textos (Fonseca, 1992b; Maingueneau, 1997, 2005; Ramos, 2003). É dessa forma, ao cruzar os conhecimentos anteriores com os fornecidos pelo texto, que o alocutário evoca imagens mentais que contribuem para compreender os implícitos que encontra na materialidade linguística do que 
lê. No entanto, cada texto pode apresentar um cenário ou nele coexistirem vários cenários, normalmente sendo estes coincidentes com os vários momentos temporais da narrativa.

No que se refere aos cenários interiores, encontra-se alguma referência a espaços coletivos e públicos, como estabelecimentos comerciais, aeroporto ou a escola. Contudo, os mais representados são, sem dúvida, os que convocam a realização de frames de espaços da casa (quarto e cozinha, principalmente). Como acontece em relação aos espaços anteriormente referidos, também estes podem aparecer de forma explícita ou implícita ao leitor.

As sequências narrativas são introduzidas no discurso por marcadores temporais que marcam a progressão do texto, como: "quando", "depois", "de repente", "a meio da tarde", "finalmente" (Giroflé, p. 72). Esses marcadores temporais permitem ao leitor acompanhar o desenrolar dos acontecimentos, situando-os no tempo. Outros marcadores linguísticos surgem com função de inscrever a narrativa no espaço. Falamos de localizadores espaciais explícitos como "praia", "rua", "casa", "escola" etc.; mas também de expressões que fornecem coordenadas espaciais que possibilitam a realização de implícitos capazes de inscrever a narrativa no espaço, como em "deitados em cima das toalhas, esperavam que o sol os enxugasse" (Pasta mágica, p. 124).

Para além da presença de marcadores temporais e espaciais, outra característica que se encontra nos textos narrativos é uma predominante seleção de verbos de ação em detrimento dos restantes verbos, estratégia que potencia o apresentar dos acontecimentos narrados, permitindo ao leitor visualizar mentalmente os eventos (frames), à semelhança da visualização de um filme.

\section{OS TEXTOS DESCRITIVOS}

Também esses textos, à semelhança dos anteriores, são recortados maioritariamente de contos. No entanto, ao contrário do que acontece com os textos narrativos, o excerto é retirado de sequências descritivas. Mas, por serem recortados do início de textos narrativos, algumas vezes, iniciam-se com a fórmula "Era uma vez...”, embora não cheguem a revelar-se verdadeiras narrativas, defraudando, desse modo, as expectativas dos leitores:

Era uma vez uma ciganinha... (Giroflé, p. 54)

Nos textos descritivos predomina um enunciador omnisciente, conhecedor do que enuncia, mas mantendo-se externo ao texto. Também em alguns desses textos se encontra a voz da enunciação caracterizada como a voz de uma criança, permitindo maior aproximação entre enunciador e criança-leitora, evocando mais facilmente os seus mundos e originando uma maior adesão às ideias que visa transmitir e às quais fazer aderir. Esse narrador é, algumas vezes, autodiegético, o que lhe permite maior protagonismo aos olhos da criança-leitora, conquistando facilmente a sua simpatia ao assumir o papel de personagem principal.

A maioria desses textos descreve situações do quotidiano das crianças-personagens, podendo também alguns deles apresentar descrição de pessoas ou estados de coisas ou acontecimentos pontuais. Os textos descritivos são, então, textos que 
apresentam a descrição dos lugares e dos mundos da criança-personagem - as suas brincadeiras, os seus momentos de lazer, os trabalhos que realiza etc. - vividos na escola, em casa ou na rua/no exterior. Essa é também uma forma de aproximação à criança-leitora que facilmente se identifica com os lugares e os contextos descritos nos manuais, pois fazem parte do seu quotidiano. Mesmo que, eventualmente, os mundos descritos não façam parte do quotidiano de todas as crianças, pela sua recorrência (nos livros para crianças, nos manuais, na televisão, no cinema, nos divertimentos e brinquedos etc.) tendem a constituir um interdiscurso ficcional da infância - um universo a que os discursos das crianças e os discursos que lhes são dirigidos se referem, recuperam e reatualizam constantemente. Nesse caso, os manuais integram o processo, dão vida a esse interdiscurso.

A acompanhar a descrição realizada nos textos, encontra-se um forte recurso ao uso da adjetivação, que contribui para caracterizar os objetos descritos, sendo essa uma estratégia que permite tornar o texto mais apelativo aos olhos do leitor. Para o conseguir, o enunciador seleciona adjetivos, muitas vezes em forma de diminutivos, que aproximam o texto da linguagem infantil; outras vezes, adjetivos que enchem o texto de mistério e magia, convocando o imaginário infantil e potenciando a adesão do leitor à leitura e às ideias por ela veiculadas. Encontra-se, ainda, o recurso à enumeração (associada a recursos retóricos) de cores, de estações do ano, de coisas, de acontecimentos, de comportamentos, etc., contribuindo para construir os cenários que servem de pano de fundo aos textos. Por vezes, as descrições servem o propósito de caracterizar comportamentos exemplares e funcionam como reportórios interpretativos que permitem à criança-leitora a criação de frames que evocam situações por si conhecidas e, muitas vezes, desejadas, o que, mais uma vez, promove a adesão do leitor às ideias do enunciador transmitidas nos textos. Podem também, pelo contrário, as descrições e enumerações aparecerem a caracterizar comportamentos incorretos, colocando uma forte carga de negatividade nessas práticas:

Quero hoje apresentar-lhes/ o meu vizinho Leitão:/ parece mesmo um porquinho,/ detesta água e sabão. (Amiguinhos, p. 140)

Nesses casos, os processos de modalização que o enunciador usa marcam a sua avaliação diante do que descreve, influenciando a forma como a criança-leitora se vai posicionar perante tais comportamentos, promovendo certo distanciamento. Aqui fica patente a força que a palavra pode adquirir, bem como o poder do discurso diante do "exercício de influência" (Fonseca, 2001) que ele realiza, condicionando as formas de pensar e agir das crianças-leitoras. É o que Bronckart (2009), no quadro do interacionismo sociodiscursivo, refere como "poder de moldar a pessoa humana" no conjunto das suas capacidades psicológicas, em contexto de “formações sociais”. É também o que, no âmbito da pragmática, refere-se ao "langage comme discours producteur d'effets, comme puissance d'intervention dans le réel" (Maingueneau, 1990, p. 1). Os "sistemas de representações sociais" (Pais, 1998) são construídos pelas normas e pelos valores transmitidos nos textos, promovendo determinadas atitudes e ideologias.

Apesar de se descreverem comportamentos negativos, com a finalidade de potenciar comportamentos positivos, por oposição ao que se apresenta como social- 
mente errado, raramente se descrevem cenários de tragédia. Essa é uma forma de afastar as crianças dos problemas do mundo real, assumindo-se a sua imaturidade para entender o que se passa à sua volta ou para ter opinião sobre as coisas do mundo. É o que Sarmento (2007) chama de "olhar adultocêntrico" sobre as crianças, reconhecendo-as como reprodutoras de cultura, mas não como (co)produtoras dessa mesma cultura, recusando-lhes o papel de "atores sociais" (Sarmento, 2007; Sarmento e Pinto, 1997) que lhes atribui a sociologia da infância.

\section{OS TEXTOS INSTRUCIONAIS}

Como se tem vindo a verificar, os manuais assumem, de forma geral, a função de educadores e socializadores da criança-leitora. Nesse sentido, os textos instrucionais contribuem em larga escala para a concretização dessa ambição socializadora, na medida em que fornecem normas de conduta social que configuram formas de ser, de estar e de agir. Confirmando essa ideia, muitos desses textos são enformados pela inclusão em rubricas como "formação cívica" (Pasta mágica), por exemplo, que, logo à partida, os dota de um objetivo ilocutório de fazer-fazer e fazer-ser. Alguns textos colocam ao aluno uma série de questões com vista a motivar a reflexão sobre o assunto em destaque. Essas questões são colocadas diretamente ao leitor (pela utilização do "tu"), construindo um quadro interativo de forte interpelação direta e no qual o locutor constrói um éthos (Amossy, 2010) de autoridade. Contudo, a interpelação é, algumas vezes, fictícia, pois encontra-se precedida de uma afirmação claramente modalizada, que possui o poder de condicionar a resposta do aluno; ao mesmo tempo em que é seguida de uma resposta à questão colocada.

Usar as mãos para bater, magoa e não está certo!

Quando alguém te bate como te sentes?

Magoado e triste.

Como se sentirá alguém a quem tu batas?

Magoado e triste, também. (Pasta mágica, p. 68)

Ou seja, formula-se uma questão (condicionada pela afirmação anterior), apresentando-se também a resposta para essa mesma questão. À criança-leitora resta interiorizar o que é dito e aceitar o discurso como verdadeiro, constituindo uma norma a seguir, moldando, assim, a sua conduta pessoal e social. Não esqueçamos que os manuais detêm um forte poder de apresentarem os discursos como inquestionáveis, ao serem considerados a versão oficial do que deve ser o conhecimento e a cultura transmitidos a determinada geração (Dionísio, 2000). Dessa maneira, apesar de as estruturas interrogativas ocorrerem de forma expressivamente interativa, a verdade é que não é esperada uma verdadeira reflexão realizada pelo leitor, uma vez que lhe são fornecidas "quase" todas as respostas nos segmentos de texto que as precedem. Assim, assegura-se a resposta harmonizada, pois o leitor limita-se a seguir as orientações dadas, respondendo às questões de forma taxativa, negligencia-se a reflexão sobre os assuntos abordados.

O enunciador serve-se de recursos que testemunham a modalidade deôntica e epistémica, com intenção de convencer o alocutário de que constitui vantagem 
para si a adesão às suas ideias, colocando-as em prática. Cria-se, portanto, da criança uma imagem de um ser que precisa de ser conduzido pelo adulto, um ser que desconhece a forma como se deve comportar na sociedade e que desconhece o que é melhor para si. Encontramos enunciados enformados pela estrutura "se p, então q" (Fonseca, 1993), nos quais se simula uma atribuição de poder ao alocutário, concedendo-lhe a possibilidade de escolha:

Se olhar para o professor, compreendo melhor.

Se me distrair, perco a explicação do professor. (Pasta mágica, p. 90)

No entanto, esse poder é apenas aparente, tratando-se de uma estratégia para viabilizar o ato perlocutório. $\mathrm{O}$ enunciador assume o papel de adulto, aquele que detém a voz da experiência e da sabedoria, do qual não se espera que o alocutário discorde. $\mathrm{O}$ enunciado é apresentado como verdadeiro e inquestionável, logo, um modelo a seguir.

Quanto às estruturas interrogativas, os verbos encontram-se tendencialmente no futuro e no infinitivo, conduzindo o leitor para uma evocação mental de imagens referentes a situações do quotidiano para responder às questões apresentadas. Nos segmentos de texto com estruturas não interrogativas, as sequências textuais são instrucionais e os verbos aparecem maioritariamente no imperativo, enformados pela força ilocutória do ato diretivo semelhante a ordenar:

Cede o teu lugar às pessoas mais velhas, grávidas ou deficientes. (Pasta mágica, p. 69)

Predominam as formas do verbo dever, marcando a intenção moralizadora do enunciador. É por meio da convocação da noção de dever que se faz ressaltar a dimensão pragmática que fica subentendida no texto - o que se pode e não pode fazer. Nos textos explicitamente instrucionais, visa-se dar instruções sobre os valores e as atitudes relacionadas com a ação individual de cada criança em seu dia a dia. Nesses casos, os implícitos ficam de lado e as ordens aparecem de forma expressa, pelo uso de verbos no imperativo. Já não há lugar a discussão dos assuntos (mesmo aparente). Pelo contrário, as ordens são dadas explicitamente com intenção de se fazerem cumprir. Em alguns casos, verifica-se que os atos diretivos impositivos são apresentados em favor do alocutário, o que, em última instância, justifica a realização desses mesmos atos. Contudo, trata-se de marcas da expressão do poder do locutor.

Nos textos instrucionais sublinha-se, ainda, o tratamento que o enunciador seleciona para se dirigir ao leitor - o "tu" enforma o discurso de certa informalidade sem, contudo, deixar margem para dúvidas quanto ao destinatário e ao que se espera dele. As ordens são explicitamente dirigidas à criança-leitora e é dela que se espera o cumprimento. Em suma, os textos instrucionais dos manuais escolares cumprem generalizadamente uma múltipla função pragmática: fazer-saber, fazer-fazer e fazer-ser. O maior poder dessa força ilocutória encontra-se nas duas últimas dimensões pragmáticas, pois têm a capacidade de condicionar a forma de agir da criança-leitora. 


\section{OS TEXTOS LITERÁRIOS}

Esse grupo de textos é constituído exclusivamente por poemas nos quais se encontram, como acontece na maioria dos textos desse tipo (principalmente os destinados à infância), um forte recurso à rima e à musicalidade dos sons contidos nas palavras. Ao mesmo tempo, também se verifica o uso recorrente de onomatopeias e repetições, estratégias muito utilizadas nos textos poéticos destinados à infância, por potenciarem a sua memorização ao aproximá-los das lenga-lengas e das cantilenas infantis. A par dessa estratégia de aproximação ao público-alvo, a evocação dos mundos infantis é realizada pela construção de frames, possibilitados pela seleção de expressões que transportam o leitor para esses mesmos mundos. Veja-se, por exemplo, a tão conhecida fórmula "quando eu for grande" (ou outras semelhantes), que serve de abertura a alguns dos textos literários:

Quando for crescida / hei-de inventar / um perfume de encantar. (Giroflé, p. 47)

$\mathrm{O}$ uso do futuro configura uma situação de visão prospetiva, evocando o frame de criança como "ser em devir", apoiado numa conceção de que esta é um ser em estado incompleto, de alguma forma assemelhando-se à conceção de criança enquanto "homúnculo" ou ser incompleto e imperfeito, como era vista pelos adultos da Idade Média; ou como "tábua rasa", conceção que se atribuía à criança ainda no século XVII, detendo os adultos o poder e o dever de a moldar. Esse frame configura também a infância como período "de passagem", algo instável e de preparação para o período "a sério" do estado adulto. Tal quadro concetual inviabiliza a visão da infância como tempo para usufruir, para cuidar, e a criança como plena no seu momento, mas antes configurada quase como adulto incompleto, que se completará quando se concretizar o desejo manifestado na utilização da fórmula "quero ser..." (ou não). Essa ideia contraria as mais recentes ideias defendidas pelos investigadores ligados à sociologia da infância, que veem a criança como ser pleno de direitos, capaz de participar na sociedade, fazendo ouvir a sua voz, e participando ativamente na construção dessa mesma sociedade. Trata-se de encarar a criança como ator social e a infância como categoria social (Sarmento e Pinto, 1997), sendo as crianças vistas como indivíduos coprodutores de cultura (Sarmento, 2000, 2004).

A utilização da tão conhecida fórmula "quando eu for grande"é, de qualquer modo, uma estratégia linguística que remete o leitor para o universo da imaginação infantil, potenciada pela atribuição da voz enunciativa à criança, que aproxima locutor e alocutário. Há, no entanto, outras formas de conseguir o mesmo objetivo evocando personagens que frequentam o universo do imaginário (por exemplo, o Pai Natal), ${ }^{3}$ assim como apelando à curiosidade tipicamente infantil:

E na noite de Natal / vejo o Pai Natal passar. (Pasta mágica, p. 62)

3 Expressão do português europeu, correspondente a Papai Noel em português brasileiro. 
Nesses textos, mais que em quaisquer outros, a estética torna-se basilar para "prender" o leitor, proporcionando-lhe prazer ao aderir a esse jogo que cria uma cumplicidade entre locutor e alocutário.

\section{OS TEXTOS EXPOSITIVOS}

Nesse conjunto de textos apresentam-se conceitos (cidadania e direitos das crianças, por exemplo), assim como ideias sobre alguém ou algum estado de coisas, não se limitando a descrever, mas também a analisar essas mesmas ideias. Aos olhos da criança-leitora, quando num texto se afirma que alguma coisa ou alguém é de determinada forma, isso significa que é verdade o que é dito - como foi aflorado antes, os textos presentes nos manuais escolares são imbuídos de um poder constitutivo aos olhos dos seus jovens leitores, como se fossem irrefutáveis fontes de verdade. ${ }^{4}$ Essa premissa sai reforçada ao ser eliminado qualquer vestígio de fonte ou enunciador prévio, assumindo-se o locutor como autoridade e a afirmação como indiscutível - é a chama "autoridade das coisas" ou "retórica da evidência" (Ramos, 2009). Nesses textos não se expõem visões distintas entre si ou opiniões conflituantes, apresenta-se "a visão das coisas" em detrimento de "uma das visões possíveis", por meio de uma modalização muito acentuada dos enunciados, assim como predomínio da utilização dos verbos ser e ter, quase sempre no presente. As crianças-personagens são configuradas como seres conformados com a sua situação pessoal e social, mesmo nos contextos mais adversos:

A vida é assim. (Amiguinhos, p. 6)

Essa configuração das personagens não aparece realizada de forma explícita, sendo utilizados implícitos cuja função pragmática é a de levar o alocutário a concluir o que o locutor deseja que conclua, sabendo que o que é dito de forma implícita tem um poder persuasivo muito maior que aquilo que se diz de forma explícita (Fonseca, 1992b; Ramos, 2003).

\section{OS TEXTOS HÍBRIDOS}

À luz do que defende Adam (1992), nos textos analisados (quase) nunca se encontra uma única sequência prototípica. Os textos são constituídos por sequências mais ou menos prototípicas que se juntam ou encaixam umas nas outras para formar um texto (ou tessitura) integral. Embora essas sequências possam ser de diferentes tipos, há sempre uma que predomina sobre as restantes, servindo esta para enquadrar o texto em determinada tipologia. Assim, todos os textos são, de alguma forma, híbridos, quando se fala exclusivamente de tipos

4 Tal como se verifica nos manuais escolares, também em artigos de divulgação científica mediática para crianças "o enunciador apresenta-se como possuindo um saber estável, definitivo, não problemático, inquestionável, num discurso que o representa, o que contrasta com o cenário próprio do saber da investigação, que é assumidamente instável, provisório, problemático, discutível” (Ramos, 2014, p. 158-159). 
de sequências textuais. Os exemplos mais representativos desse hibridismo são aqueles que apresentam uma sequência expositiva que antecede uma sequência marcadamente instrucional.

Ser bem-educado é pedir por favor, quando queremos alguma coisa. [...]

Se não perceberes uma explicação pede, por favor, para explicarem novamente. (Pasta mágica, p. 18-19)

Essas sequências expositivas encontram-se ao serviço da intenção do enunciador de instruir pela exposição de ideias que apresenta como irrefutáveis, funcionando como sequências preparatórias do ato diretivo que se segue na sequência instrucional, aumentando a probabilidade de concretização desse mesmo ato.

\section{CONCLUSÕES}

Tendo por base os pressupostos teóricos e metodológicos identificados, selecionaram-se os textos dos manuais escolares de português para perceber que imagens neles se constroem das crianças e da infância, convictos de que essas imagens, pelo estatuto que os manuais assumem na sociedade, influenciam a forma de pensar, ser e agir das crianças-leitoras, bem como normalizam essas mesmas imagens, que não são mais do que construtos sociais e ideológicos. Esses textos foram organizados segundo sequências prototípicas dominantes e de acordo com a classificação oficial sugerida pelo Dicionário Terminológico: narrativos, descritivos, instrucionais, literários e expositivos. Não foram identificados no corpus de análise textos argumentativos, preditivos e conversacionais. Os textos dos manuais são sempre enformados por dois enfoques distintos: o do autor do texto-origem e o do autor do manual. Os autores dos manuais selecionam determinadas tipologias textuais condicionados pelas diretrizes emanadas do poder político (pelos currículos vigentes) e pela necessidade de transmitir determinados conceitos, valores e atitudes, tradicionalmente associados à escola e dos quais ela se assume como promotora. Embora os pais sejam os primeiros educadores, a escola sempre assumiu o papel de educadora de massas, educadora de uma consciência coletiva que se quer harmoniosa e consistente, para garantir unidade e estabilidade social. Mas o autor do texto/manual inscreve nele também as suas crenças e os seus valores pessoais, e o texto/manual assume-se como modelador de mentes e de condutas.

Independentemente da tipologia que enforma os textos, o enunciador assume-se como voz autorizada e configura o texto tornando-o protótipo de condutas socialmente aceites. É nesse sentido que os textos/discursos assumem o seu estatuto de construtos sociais, no quadro de um interacionismo sociodiscursivo. $\mathrm{O}$ enunciador convoca a enciclopédia de saberes que partilha com os leitores eleitos e recorre a processos de modalização para conferir ao seu discurso o valor da irrefutabilidade, fazendo crer que perfilha ideias e valores hegemónicos. É nessa enciclopédia de saberes que estão "arquivados" e disponíveis os reportórios interpretativos adotados e compartilhados pelos membros da sociedade, cujo 
reconhecimento possibilita a construção de frames que garantem a compreensão leitora pela realização de inferências (Castro, 2014).

Em relação às tipologias textuais, verificou-se que predominam os textos narrativos e que isso vem sendo hábito na conceção dos manuais escolares de português em Portugal, que constituem verdadeiras antologias textuais. Nesses textos encontram-se sempre crianças muito corretas, obedientes e bem-comportadas, semelhantes às apresentadas nos manuais do Estado Novo (período de ditadura durante o século XX) (Castro e Ramos, 2014). Os textos instrucionais, também significativamente representados, vêm corroborar essa ideia e deixam instruções a seguir pelas crianças-leitoras que mais parecem conselhos dados às crianças do início do século passado. São, portanto, textos desatualizados da realidade em que as crianças-leitoras vivem e, a par desse facto, falta maior diversidade de tipologias textuais: os textos publicitários são escassos, faltam textos com hiperestruturas (como o hipertexto da internet, por exemplo), ${ }^{5}$ faltam textos autênticos com que as crianças se deparam no dia a dia e faltam textos verdadeiramente escritos por crianças. Mas falta também diversidade nos temas tratados. As crianças não precisam só de contactar com textos que lhes deem conselhos e lhes indiquem o caminho a seguir, como se a vida fosse feita de uma só possibilidade de caminho e não de múltiplas escolhas com outras tantas consequências. Nesse sentido, faltam textos que abordem temas questionadores ou fraturantes, que promovam a reflexão e a crítica (mas sem que seja dada a resposta à criança, como acontece em muitos dos casos analisados). Faltam textos que saiam da dicotomia certo/ errado e que deixem margem para a criança pensar por si só, possibilitando-lhe a oportunidade de se manifestar sobre o que lê e sobre o mundo.

Como dito anteriormente, os manuais em estudo estiveram em vigor até ao final do ano letivo 2012/2013. Findo esse período, novos manuais chegaram às escolas portuguesas, reconhecendo-se uma evolução na seleção e apresentação dos textos nos manuais de português: os excertos textuais respeitam mais os textos originais, contêm referências bibliográficas que permitem (tentar) encontrar os textos originais e reconhece-se um esforço por incluir diferentes tipologias textuais. ${ }^{6}$ No entanto, continuam a predominar os textos narrativos, e os manuais continuam a ser verdadeiras antologias de textos, mas, mais importante que isto, parecem continuar na senda da dicotomia certo/errado, conduzindo a criança para uma forma de ser e estar estereotipada, não contribuindo para a incentivar a pensar por si, antes a formatam para determinado modo de estar na vida que contribui para a estabilidade social, é certo, mas não para a construção de cidadãos conscientes, críticos e interventivos.

5 Sobre o uso da organização hiperestrutural de textos de divulgação científica mediática para crianças, ver Souza e Giering (2009); Giering (2012); Souza (2013); Ramos (2014); Ramos, Marques e Duarte (2015).

6 As Metas Curriculares de Português (Buesco, 2012, p. 328) estipulam que o aluno deve ler os seguintes tipos de texto no $4^{\circ}$ ano de escolaridade: "narrativos, descrições, retratos, notícias, cartas, convites, avisos, textos de enciclopédias e de dicionários, e banda desenhada”. 


\section{REFERÊNCIAS}

ADAm, J.-M. Éléments de linguistique textuelle: théorie et pratique de l'analyse textuelle. Liège: Mardaga, 1990.

. Les textes: types et prototypes. Liège: Mardaga, 1992

ADÃo, A. A regulação da convivência e da disciplina nos liceus oitocentistas: o discurso normativo. In: Fernandes, R.; Vidigal, L. (Coords.). Infantia et pueritia: introdução à história da infância em Portugal. Santarém: Escola Superior de Educação de Santarém, 2005. p. 211-218.

Amossy, R. La présentation de soi. Ethos et identité verbale. Paris: Presses Universitaires de France, 2010.

Apple, M. Manuais escolares e trabalho docente: uma economia política de relações de classe e de género na educação. Lisboa: Plátano Editora, 2002.

Ariès, P. História social da criança e da família. Rio de Janeiro: Zahar Editores, 1981.

Austin, J. L. How to do things with words. Oxford: Clarendon, 1962.

Bakhtine, M. Estética da criação verbal. São Paulo: Martins Fontes, 1992.

Bastos, G. Literatura infantil e juvenil. Lisboa: Universidade Aberta, 1998.

Benveniste, E. Problèmes de linguistique générale I. Paris: Gallimard, 1975.

Bronckart, J.-P. Le fonctionnement des discours. Paris: Delachaux \& Niestlé, 1985.

. Atividades de linguagem, textos e discursos. Por um interacionismo sociodiscursivo. São Paulo: Educ, 2009.

Brougère, G. A criança e a cultura lúdica. Revista da Faculdade de Educação, São Paulo: USP, v. 24, n. 2, jul./dez. 1998. Disponível em: <http://www.scielo.br/scielo. php?script=sci_arttext\&pid=S0102-25551998000200007>. Acesso em: 11 out. 2017.

Buesco, H. C. et al. Metas Curriculares de Português. Lisboa: Ministério da Educação e Ciência, 2012.

Castro, R. V. et al. (Orgs.). Manuais escolares: estatuto, funções, história. Braga: Centro de Estudos em Educação e Psicologia, Instituto de Educação e Psicologia da Universidade do Minho, 1999.

CAstro, T. Texto e fragmento textual: processos de re(con)textualização. Tese (Mestrado) - Universidade do Minho, Braga, 2007.

. Texto e fragmento textual: processos de re(con)textualização. Diacrítica: Série Ciências da Linguagem, Braga: Universidade do Minho, n. 22/1, p. 157-184, 2008.

. Representaçôes da infância no manual escolar: uma abordagem linguística dos textos de manuais do $4^{\circ}$ ano de português. Tese (Doutoramento) - Universidade do Minho, Braga, 2014.

Castro, T.; Ramos, R. Representações da infância no manual escolar em Portugal. Revista Vozes dos Vales: publicações acadêmicas, Diamantina: UFVJM, ano III, n. 6, p. 1-32, 2014.

Charaudeau, P.; Maingueneau, D. Dicionário de análise do discurso. São Paulo: Editora Contexto, 2006. 
Choppin, A. Les manuels scolaires: histoire et actualite. Paris: Hachette, 1992.

Claudino, S. Os manuais escolares da $1^{\text {a }}$ República à actualidade. Os insubmissos. In: Duarte, J. B. (Org.). Manuais escolares: mudanças nos discursos e nas práticas. Lisboa: Edições Universitárias Lusófonas, 2011. p. 73-95.

Correia, A. C. L. A normalidade imaginada: a fabricação da anormalidade escolar através do processo de implementação da escolaridade universal e obrigatória, na viragem do século XIX para o século XX. In: Fernandes, R.; Vidigal, L. (Coords.). Infantia et pueritia: introdução à história da infância em Portugal. Santarém: Escola Superior de Educação de Santarém, 2005. p. 192-210.

Crispim, M. L. Edição e informatização de textos. In: Mateus, M. H.; Correia, C. N. (Orgs.). Saberes no tempo: homenagem a Maria Henriqueta Costa Campos. Lisboa: Edições Colibri, 2002. p. 271-278.

Dionísio, M. L. T. A construção escolar de comunidades de leitores. Coimbra: Almedina, 2000.

Fernandes, R.; Vidigal, L. (Coords.). Infantia et pueritia: introdução à história da infância em Portugal. Santarém: Escola Superior de Educação de Santarém, 2005.

Fillmore, C. An alternative to checklist theories of meaning. In: Proceedings of the First Annual Meeting of the Berkeley Linguistic Society. Berkeley: BLS, 1975. p. 123-131.

FonsecA, J. Linguística e texto/discurso: teoria, descrição aplicação. Lisboa: ICALP, 1992a. . Ensino da língua materna como pedagogia dos discursos. In: . Linguistica e texto/discurso: teoria, descrição aplicação. Lisboa: ICALP, 1992b. p. 235-248. . Pragmática dos enunciados vazados nas sequências " $p$ ! e q" e " $p$ ! ou q". In: . Estudos de sintaxe-semântica e pragmática do português. Porto: Porto Editora, 1993. p. 149-179. (Coleção Linguística, n. 1).

. Pragmática linguística, introdução, teoria e descrição do português. Porto: Porto Editora, 1994. (Coleção Linguística, n. 5).

. "Viva a Guiné-Bissau": a construção do sentido e da força persuasiva do discurso. In: Linguística, n. 14).

Foucault, M. L'archéologie du savoir. Paris: Gallimard, 1969.

Giddens, A. Sociologia. Lisboa: Fundação Calouste Gulbenkian, 1997.

Giering, M. E. Referenciação e hiperestrutura em textos de divulgação científica para crianças. Linguagem em (Dis)curso, Tubarão: UNISUL, v. 12, n. 3, p. 683-710, 2012.

Kerbrat-Orecchioni, C. La conversation. Paris: Seuil, 1996.

Lopes, A. M. "Crianças ao desamparo": a representação da criança pobre na Imprensa Regional de Setúbal (1900-1935). In: Fernandes, R.; Vidigal, L. (Coords.). Infantia et pueritia: introdução à história da infância em Portugal. Santarém: Escola Superior de Educação de Santarém, 2005. p. 67-98.

Magalhães, J. P. Um contributo para a história da educação da infância em Portugal. In: Pinto, M.; Sarmento, M.J. (Coords.). As crianças: contextos e identidades. Braga: Centro de Estudos da Criança da Universidade do Minho, 1997. p. 115-145. 
Maingueneau, D. Pragmatique pour le discours littéraire. Paris: Bordas, 1990. . Aborder la linguistique. Paris: Seuil, 1996. . Novas tendências em análise do discurso. Campinas: Pontes, 1997. . Gênese dos discursos. Curitiba: Criar Edições, 2005.

Moore, S. Sociologia. Lisboa: Publicações Europa-América, 2002.

PAIs, J. M. (Coord.). Geraçöes e valores na sociedade portuguesa contemporânea. Lisboa: Instituto de Ciências Sociais da Universidade de Lisboa, 1998.

Potter, J.; Wetherell, M. Discourse and social psychology. Beyond Attitudes and Behaviour. London: Sage, 1987.

Ramos, R. Linguística e ensino da língua materna: evidências e projectos no IEC. In: Carvalho, G. S. et al. (Orgs.). Saberes e práticas na formação de professores e educadores. Actas das Jornadas DCILM 2002. Braga: Departamento de Ciências Integradas e Língua Materna/ Instituto de Estudos da Criança/ Universidade do Minho, 2003, p. 87-102.

Ramos, R. O discurso do ambiente na imprensa e na escola: uma abordagem linguística. Lisboa: Fundação Calouste Gulbenkian/Fundação para a Ciência e a Tecnologia, 2009. . Construção dos objetos de discurso em artigos mediáticos de divulgação científica para crianças. Redis: Revista de Estudos do Discurso, Porto: Universidade do Porto, n. 3, p. 156-183, 2014.

Ramos, R.; Marques, M. A; Duarte, I. M. Hiperestrutura em textos mediáticos de divulgação científica para crianças. In: Marques, M. A.; SAnchéz Rei, X. M. (Eds.). Novas perspectivas linguísticas no espaço galego-português. Corunha: Universidade da Corunha, 2015. p. 133-149.

Ramos, R.; Ramos, A. M. Children's literature and the promotion of environmental ethics in Portugal. Portuguese Studies, Cambridge: Modern Humanities Research association, v. 31, n. 1, p. 94-106, 2015.

Rasmussen, K. Places for children: children's places. Childhood, Thousand Oaks: Sage, p. 155-173, may 2004. Disponível em: <http://chd.sagepub.com/content/11/2/155. abstract>. Acesso em: 17 jul. 2012.

Sacristán, J. G. O aluno como invenção. Porto: Porto Editora, 2003.

SARmento, M. J. Lógicas de aç̧ão nas escolas. Lisboa: Instituto de Inovação Educacional do Ministério da Educação, 2000.

As culturas da infância nas encruzilhadas da segunda modernidade. In: Sarmento, M. J.; Cerisana, A. B. (Coords.). Crianças e miúdos: perspectivas sociopedagógicas da infância e educação. Porto: Asa, 2004. p. 9-34.

. Gerações e alteridade: interrogações a partir da sociologia da infância. Educação

E' Sociedade, Campinas: UNICAMP, v. 26, n. 91, p. 361-378, 2005. (Dossiê Temático Sociologia da Infância: Pesquisas com Crianças).

. Visibilidade social e estudo da infância. In: Vasconcellos, V. M. R.; Sarmento, M. J. (Orgs.). Infância (in)visível. Rio de Janeiro: Vozes, 2007. p. 25-49. 
Sarmento, M.J.; Pinto, M. As crianças e a infância: definindo conceitos, delimitando o campo. In: Pinto, M.; Sarmento, M.J. (Coords.). As crianças: contextos e identidades. Braga: Centro de Estudos da Criança da Universidade do Minho, 1997. p. 7-30.

Searle, J. Speech acts: an essay in the philosophy of language. Cambridge: Cambridge University Press, 1969.

Souza, J. A. C. Texto e discurso no infográfico de Divulgação Científica Midiática (DCM). Calidoscópio, São Leopoldo: UNISINOS, v. 11, n. 3, p. 229-240, 2013.

Souza, J.A. C.; Giering, M.E. O infográfico: a multimodalidade e a semiolinguística. Revista da ANPOLL, Florianópolis: UFSC, v. 27, n. 2, p. 73-98, 2009.

VAN Dijк, T. A. (Éd.). Handbook of discourse analysis. 4 v. London: Academic Press, 1985.

\section{SOBRE OS AUTORES}

Teresa da Conceição Mendes de Castro é doutora em estudos da criança pela Universidade do Minho (Portugal). Professora da mesma instituição. E-mail: castro.te@gmail.com

Rui Manuel do Nascimento Lima Ramos é doutor em linguística pela Universidade do Porto (Portugal). Professor da Universidade do Minho (Portugal). E-mail: rlramos@ie.uminho.pt 